\title{
Scenarios of Mentor Education in Romania - Towards Improving Teacher Induction
}

Mihaela Stîngu*1, Eve EisenschmidT² ${ }^{2}$, AND Romiță IUCU ${ }^{3}$

$\approx$ The aim of this paper is to examine the induction programme for newly qualified teachers and mentor education in Estonia, providing a comparative analysis of existing Estonian and possible Romanian models of mentoring. While the Estonian induction programme has been in place for more than ten years, induction in Romania is a relatively new and has only been mandatory since 2011 (National Law of Education 1/2011). The specifics of mentor professional development within the Romanian induction framework have yet to be explicated. This paper proposes two possible scenarios suitable for the Romanian system :1) long-term regulated academic education (part of master or doctoral level studies), and 2) flexible short-term in-service education. The advantages and disadvantages of both models are examined and ways to overcome some of the disadvantages are identified. Ultimately, the paper proposes that a flexible, needsdriven system which encompasses a degree of choice will best fulfil the professional development needs of teachers who wish to become mentors.

Keywords: induction mentors, novice teachers, policy scenarios

$1{ }^{*}$ Corresponding Author. University of Bucharest, Romania; mihaela.stingu@fpse.unibuc.ro.

2 Tallinn University, Estonia.

3 University of Bucharest, Romania. 


\section{Scenariji izobraževanja mentorjev v Romuniji - $\mathrm{k}$ izboljševanju pripravništva učiteljev}

Mihaela Stîngu, Eve Eisenschmidt in Romiță IUCU

$\propto$ Namen prispevka je pregled programa pripravništva za na novo usposobljene učitelje in mentorje izobraževanja v Estoniji pa tudi primerjalna analiza obstoječih estonskih in mogočih romunskih modelov mentorstva. Če so programi za uvajanje v Estoniji v praksi že več kot deset let, so programi pripravništva $\mathrm{v}$ Romuniji sorazmerno novi in obvezni šele od leta 2011 (National Law of Education 1/2011). Značilnosti profesionalnega razvoja mentorjev znotraj okvira uvajanja v Romuniji morajo šele biti razdelane. Prispevek predlaga dva mogoča scenarija, prilagojena romunskemu sistemu: 1) daljše regulirano univerzitetno izobraževanje (v okviru magistrskih ali doktorskih študijskih programov) in 2) krajše fleksibilno usposabljanje v okviru programov izpopolnjevanja. Preučene so prednosti in slabosti obeh modelov ter predstavljeni mogoči načini spoprijemanja $z$ določenimi slabostmi. Nazadnje je v prispevku predlagano, da bi fleksibilen in glede na potrebe orientiran sistem, ki obsega določeno stopnjo izbirnosti, najbolje zadostil profesionalnemu razvoju učiteljev, ki želijo postati mentorji.

Ključne besede: mentorji pripravništva, na novo usposobljeni učitelji, scenariji politik 


\section{Introduction}

Teachers' professional development has become a priority for policy makers at the EU level, as the most powerful aspect implementing innovative and active pedagogies, such as interdisciplinary teaching and collaborative methods, and to enhance the development of relevant and high-level skills and competences while fostering inclusive education (New priorities for European cooperation in education and training, 2015, p.11). Several measures have been introduced to strengthen teachers' qualification in member states (Strengthening teaching in Europe, 2015). In this context, initial teacher education, the induction of newly qualified teachers, and continuing professional development of teachers have become the subject of discussions and policy developments in member states.

Concerning the induction of newly qualified teachers, one relevant document with regards to the development of clear educational policies at the European level is Developing coherent and system-wide induction programmes for beginning teachers - a handbook for policymakers, elaborated by the European Commission in 2010. The document states that there is no single model of effective induction policies. The induction programmes may be voluntary or compulsory, localised or nationwide; they may or may not be linked to probationary periods or to the assessment of teacher competences. This document gives a good frame for the analysis of the context in which an induction system for teachers can be implemented and how to design induction programmes.

A primary focus for researchers for many decades has been on the mentor, as a key figure in induction programmes, who supports the socialisation of novice teachers to the school context and their professional development (Feiman-Nemser, 2001). Reoccurring questions concern the role and tasks of the mentor, selection process, and preparation for successful cooperation with the newly qualified teacher (Jones, 2010).

The main criterion upon which mentors are appointed to their positions is experience. Bullough (2005) emphasises the fact that it is not obvious that a good teacher can automatically become a good mentor, or that they have sufficient experience to provide adequate support for teachers in their first year of practice. In order to analyse mentor education in the context of induction programmes, Ulvik and Sunde (2013) conducted a study within a mentor education programme to gain a deeper understanding of mentor preparation and to analyse the relevance of mentor education in the context of induction programmes. They (ibid.) concluded that though mentors fulfil their tasks effectively when they were prepared for this role, mentor training is sporadic and 
unstructured. Ingleby and Hunt (2008) state that induction mentors should have a professional status and the professionalisation of the induction mentors is one way to improve the quality of mentorship. Gravey and Alred (2000, cit. in Yee \& Fan Tang, 2012) underscore the need to take into consideration two aspects in educating induction mentors: (1) mentoring as a subject in itself (fundamental knowledge about mentoring novice teachers), and (2) professional development of mentors working in different contexts (mentor practice).

Compiling mentor education programmes, the context in which mentor education should take place and the role of mentors in an induction programme need to be analysed. Thereby, in educating induction mentors, we have to consider that mentoring can be approached through identifying goals and focusing on objectives, which addresses educational systems in different countries.

Wang and Odell (2002) define mentoring based on three approaches: 1) humanistic interactions: focus is on novice teacher personal needs and wellbeing; 2) situated apprenticeship: focus is on adjustment to the school culture, supports the development of teaching skills in particular context; and 3) critical constructivist approach: focus is on transforming teaching in collaborative inquiry. Orland-Barak and Klein (2005) proposed similar approaches to mentorship: therapeutic (orientation to personal growth), apprenticeship (modelling of various behaviours), and reflective (inter-subjective process). From the perspective of beginning teacher's development, mentoring can focus on three dimensions: 1 ) the professional dimension, the emphasis is on developing teaching competences; 2) the social dimension, the emphasis is on supporting the beginning teacher to become a member of the school organisation; 3 ) the personal dimension, the process of development of a professional identity as a teacher is in focus, including teacher's self-efficacy, emotions and self-esteem (Eisenschmidt, 2006). Nevertheless, there is no 'one size fits all' solution concerning the preparation of induction mentors, and every country should create their own system that best meets the aims of the national educational system and suits the particular educational context.

When identifying possible mentor education scenarios, we have to consider that any changes or reforms in education must be seen within a more general social and political context, and located within a particular historical, political, and educational tradition (Hartnett \& Carr 1995, p. 41). Therefore, regardless of the country specific context, it is not possible to borrow models or scenarios from other systems and implement models in the same way. While planning change and implementing new programs in teacher education, it is necessary to take into account both national contexts, but also learn from others. Thus, it is important to analyse other experiences; the reforms have to be 
planned and worked out locally, taking into account the national social, political, and educational contexts.

\section{Methodology}

The aim of this paper is to analyse the contexts and models of mentor education in two European countries, Estonia and Romania, and to propose mentor education scenarios for the Romanian context. When identifying mentor education alternatives for the Romanian system, we analysed the experience of the Estonian induction system, which was implemented more than ten years ago. We used the Estonian model as an explanatory case, which supports our reflective analysis.

Firstly, we identified the national regulations concerning induction to determine the status of the mentors and how mentor education is regulated within the two countries. The documents we reviewed are the following: 1) legislation on teacher education in Estonia and Romania; 2) research papers and reports on planning and implementing induction programmes in Estonia and Romania; 3) the European Commission reports on teacher education.

Secondly, we proposed alternative policy scenarios for the Romanian system. We considered that approaches on mentor education depend on local contexts and should support continuity in teachers' professional development through three phases: initial education, induction, and continuing education.

We identified the advantages and disadvantages of the scenarios and proposed a possible scenario for implementation in the Romanian educational context.

\section{Teacher Education System and Teacher Induction in Estonia}

Estonia is the northernmost of the three Baltic States with a population of 1.34 million people. Approximately 14,500 teachers are employed in around 540 general education schools (Haridussilm). The Estonian higher education system was reformed in 2006 according to the Bologna regulation into a three-year bachelor level degree and two-year master level degree. According to the policy, teacher education is obtained through master level education offered by two universities. Currently, three initial teacher education models are used: the master level five-year integrated model (class teachers in primary school level), in which subject and educational studies take place concurrently, and the two-phase or consecutive model (for subject teachers), in which a two-year master level teacher education is started 
after the completion of three-year subject studies at the bachelor level. Vocational and pre-primary school teachers have to obtain three-year bachelor education.

The one-year induction programme for newly qualified teachers with mentor support has been offered since 2004. The contextual reasons implementing support programmes for newly qualified teachers were described during the preparation process of the induction programme as the following:

1. Studying to become a teacher is not popular among young people, and the number of applicants to teacher education is decreasing, and at the same time the average age of teaching staff is increasing;

2. During the first five working years, many teachers leave school and attempt to find jobs in other fields; thus, the educational system loses educated teachers, and the resources are not used effectively. Newly qualified teachers quit the profession because of the difficulties during their first years of teaching. The reasons for their leaving are focused on the complexity of the teacher's job, inaccurate expectations (idealistic approach to the teacher's work) and acquired initial teacher education that does not meet the real needs;

3. The views and beliefs about becoming a teacher have changed, teachers are lifelong learners and continuing stages should be implemented. A teacher's first-year experience has a strong influence on the development of the teacher's identity and development of teaching competences (Eisenschmidt, 2006).

The Estonian school system is decentralised, and schools are highly autonomous. Additionally, school leaders are responsible for hiring new teachers, planning teachers' workload, and evaluating the need for teachers' professional development and organising activities to support teachers' learning.

The theoretical foundations of the induction programme and mentor education in Estonia were agreed as follows (ibid.):

- $\quad$ Schools are learning organisations; teachers form learning communities and support each other's professional development;

- $\quad$ Entering the profession and organisation evolves socialisation processes through which the novice teacher becomes a member of the teaching community.

- The basis for the continuous professional development of a teacher is the readiness to self-reflection. In order to ensure the continuity of the professional development of teachers, it is essential to connect the three stages of development: initial training, induction year and continuous professional development. 
The Estonian induction system has partly been influenced by systems and initiatives in England, the Republic of Ireland, the United States, and Nordic countries (ibid.). Practices and initiatives in these countries were analysed from the perspective of teachers' professional development as a continuous process, including education, induction period (socialisation, entering the profession) and continuing in-service education.

According to the education policy, mentors in Estonia should have at least 3-years of teaching experience and have a special mentoring education (Framework Guidelines for Teacher Education, 2000). It is not necessary for the mentor to be a teacher of the same subject, but it is recommended that they teach in the same field and at the same school level.

The mentor's task in the induction program is to support a novice teacher's professional growth and socialisation at school as an organisation. Furthermore, competent mentors can support the school administration to create a cooperative and reflective school culture. The following figure illustrates the mentors' expected activities during the induction period (Figure 1).

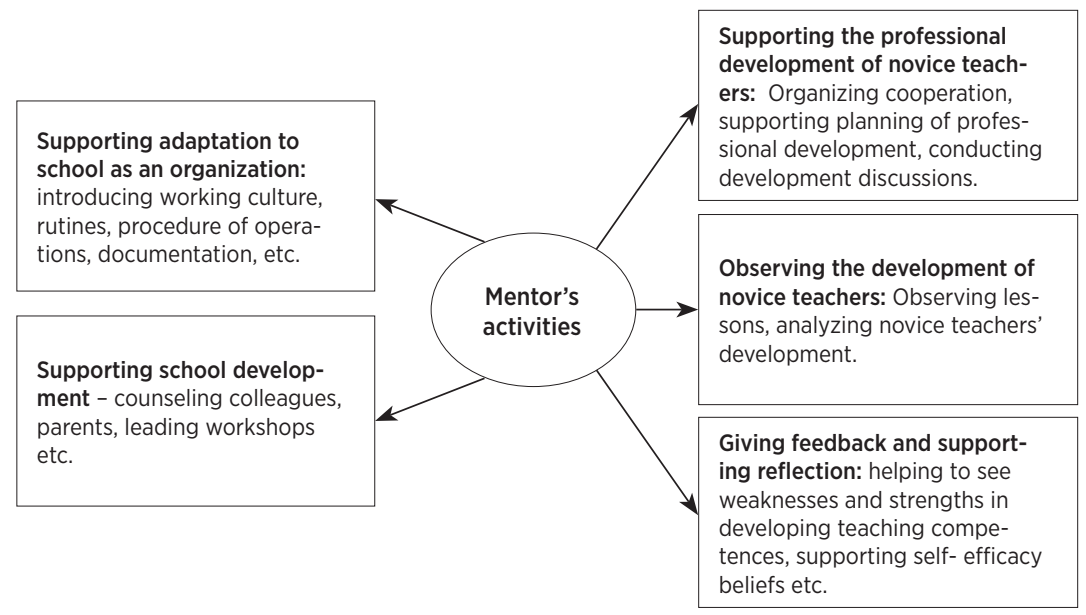

Figure 1. Mentor's activities (adapted from Eisenschmidt, 2006, p. 62; PoomValickis, 2007, p. 57)

Acting as a mentor requires the development of certain specific competences. Therefore, the aim of mentor education is to support the acquiring of mentoring- specific counselling competences and formulating attitudes to support collegial learning and professional development (Poom-Valickis, 2007). According to the teacher education policy, universities provide a oneyear ECTS mentor education course in the amount of 12, which is financed by 
the Ministry of Education and Research. This course is acknowledged as part of teachers' continuing professional development and the participants obtain an academic certification. When creating the content of a mentor education course, the results of research studies addressing the main concerns of beginning teachers were considered. The concept of mentor teachers as teacher educators was followed; specifically, the mentor's role is not only supporting socialisation and providing emotional support but also fostering the novice teacher's professional development and learning through dialogue and reflection. The course consists of the following modules:

1. School as a learning organisation, novice teacher in an organisation, socialisation into the organisation, collaborative learning, and work-place learning;

2. Supporting novice teacher professional development. Mentoring. Mentoring as dialogue. Communicative skills: listening, giving feedback, supporting reflection;

3. Contemporary learning approach (constructive learning process, student-centred learning) (Eisenschmidt, 2006, p. 67).

When selecting mentors, personal characteristics such as commitment to the profession, empathy, and willingness to support colleagues' professional development should be considered (Löfström \& Eisenschmidt, 2009). These characteristics are equally important when fostering a good mentorship relation.

\section{Teacher Education System and Mentor Education in Romania}

Considering Romanian education statistics, in 2015/2016, there were 237,443 teachers in 7,108 general education institutions (National Institute of Statistics, 2015). According to regulations, preschool, and primary class teachers must undergo a three-year bachelor degree programme in education. Subject and vocational teachers must obtain an integrated five-year master level education.

Based on educational reform in Romania (National Law of Education, 1/2011) there has been a change of paradigm from the concurrent approach in initial teacher education to the consecutive approach. The new law states that initial teacher education includes subject education, which is achieved during three-year bachelor studies and continuing two-year master level teacher education. However, the policy has not been implemented, and initial teacher 
education takes place according to the concurrent model. In the context of lifelong learning, all in-service teachers have to pass professional development courses based on their personal needs in an amount of at least 9o ECTS every five years. First-time one-year induction in a school, under the guidance of a mentor teacher, is emphasised on a policy level.

The concept of induction and induction mentors in Romania is relatively new and has only gained recognition since 2011 when the new National Law of Education (1/2011) was approved. There are numerous grey areas regarding the implementation of the induction programme, the role of mentor, and specific mentor education. There is no clarity yet, although the policy states that teachers who would like to become mentors need to have at least eight years of teaching experience, and must pass at least one course accredited by the Ministry of Education within the previous five years. According to the legislation, in order to become a mentor, the eligible teacher must pass a specific exam in two phases: 1) giving a lesson or organising other teaching activity; 2) observing other teacher's lessons or teaching activity and analysing it.

Taking into consideration the structure and organisation of the educational system, in Romania, even if the decentralisation of the educational system has been stated in the National Law of Education since 2005 (Decentralization strategy of undergraduate studies, 2005), to date the decentralisation process has not been fully implemented. Therefore, the Ministry of Education and County Schools Inspectorates are in charge of the administration of schools and other educational institutions. Additionally, there are several institutions regulating the field of teacher education. The National Authority for Qualifications is an agency under the governance of the Ministry of Education coordinating the quality assurance of adult education, including teacher education; coordinating the authorisation of training providers; coordinating the authorisation of professional competency evaluation centres for adults, including teachers; and participating in the development of plans and programs of national interest in the qualifications and training of adults including teachers. There is one more participant: the Romanian Agency for Quality Assurance in Higher Education (ARACIS), as part of the Ministry of Education. The role of this agency is to authorise and evaluate higher education institutes and their programmes.

Concerning the continuing professional development of teachers, Schools Inspectorates organise and guide these activities. To date, there are no regulations about the responsibilities of Schools Inspectorates regarding the induction of newly qualified teachers and mentor education.

To sum up, many unanswered questions remain concerning the implementation of an induction programme for newly qualified teachers. One of the 
most crucial aspects of the induction, the role of the mentor and mentor education, needs deeper analysis prior to regulation. Thus, this creates the need for the proposals of possible scenarios, which suit the Romanian context.

\section{Induction Mentors Education: proposed scenarios}

One of the central questions regarding designing the mentoring system is: what is the best way to integrate mentor education into the teachers' continuing professional development (CPD) system? We propose and analyse further the following two scenarios: 1) long-term regulated academic education (part of master or doctoral level studies, in which mentor education is one specialisation), and 2) flexible short-term in-service education in which the main focus is on mentoring (Iucu \& Stîngu, 2013).

The first scenario $\left(\mathrm{S}_{1}\right)$ is a highly regulated, centralised, academic system, in which the central institution takes the responsibility with multiple roles including authorisation, quality assurance, and guidance (ministry through specialised departments, e.g. National Authority for Qualifications, ARACIS). This creates a unique route of in-service education at the national level (Figure 2). As academic degree programmes (educational master or professional $\mathrm{PhD}$ ) are standardised and structured on a policy level; as a result, these programmes are will be long-term and less flexible. In this scenario, providers can only be higher education institutions.

The second scenario $\left(\mathrm{S}_{2}\right)$ is a regulated, but more flexible solution (Figure 2). In this case, School Inspectorates are responsible for the regulation of mentor education as one area of teachers' professional development. This institution creates a framework for mentor education programmes, and more precisely, the elaboration of mentor education may be left at the schools' level. In this scenario, the role of the schools would be to identify the needs of the newly qualified teachers and to choose the best option that fits those needs, taking into consideration the framework created by School Inspectorates. This approach is specific on-the-job education and can be considered to be the continuing in-service education of the teachers. Training providers are diverse: higher education institutions, NGOs, Institute of Educational Sciences, private organisations, professional associations, etc. These types of programmes can vary from short-term academic programmes, career training, to mobility programmes that can be of a modular type or short-term programmes. 


\begin{tabular}{|c|c|c|}
\hline Criteria & $\begin{array}{l}\text { Scenario 1: higly regulated, } \\
\text { centralized system }\end{array}$ & $\begin{array}{l}\text { Scenario } 2 \text { : low regulated system, } \\
\text { more flexible }\end{array}$ \\
\hline $\begin{array}{l}\text { Regulatory } \\
\text { Institutions }\end{array}$ & $\begin{array}{l}\text { Ministry of National Education } \\
\text { (National Authority for Qualification) }\end{array}$ & Schools \\
\hline Providers & Higher Education Institutes & $\begin{array}{l}\text { Hihher Education Institutes, } \\
\text { NGOs, IES, private organizations, } \\
\text { professional associtiations, Teacher' } \\
\text { House }\end{array}$ \\
\hline Types of programs & Master/Professional Doctorate & Short-term, in-service, modular type \\
\hline $\begin{array}{l}\text { Professionalizetion } \\
\text { route }\end{array}$ & $\begin{array}{l}\text { Less flexible, coherent at national } \\
\text { level }\end{array}$ & $\begin{array}{l}\text { Flexible route, but relatively } \\
\text { coherent }\end{array}$ \\
\hline
\end{tabular}

Figure 2. Proposed scenarios comparison (Stîngu, 2013)

We will analyse the advantages, disadvantages of the presented scenarios as well as how to overcome some of the disadvantages.

\section{Long-term regulated academic education}

From the perspective of teachers' professionalism and the prestige of the academic programmes, such as a master (or even doctoral studies) with the specialisation of the mentoring, the highly regulated centralised system is clearly in favour of such a perspective. The option of educating mentors through lengthy academic programmes is justified by a series of advantages for both the educational system and stakeholders (mentors, schools, universities, etc.). Academic programmes provide high recognition for mentors and reflect coherence and continuity throughout all phases of teacher education from initial education to induction and continuous professional development. This regulated system, with a higher academic degree, gives a good basis to create resources and network with academic institutions for mentors (i.e. handbooks, guidance, materials, etc.). Another advantage of such a system consists in the expertise and competence of the academics of the programme. Master education programmes foster the development of a strong research base for mentor education and also facilitate the formation of research capacity of future mentors. From this perspective of a mentor as a researcher, the mentor education will have great potential to support teachers' professional development.

However, considering mentor education as academic master-level education, we can identify some disadvantages. First, this is time-consuming, and there will be a gap of at least two years before the first mentors will have been educated, this approach will be unable to meet the immediate needs of the mentors at schools. Thus, there is an option that when mentorship is needed, the preparation is still in process. While on the other hand, when the mentor graduates, the programme there might no longer be a need for mentorship in 
that school. Additionally, it will take several years to educate mentors for all schools in Romania. Second, this scenario is resource intensive. A two-year master level education is expensive and possibly limits the number of future mentors. The third limitation is that academic programmes have a specific structure, and the primary focus of a master level programme is to develop the academic knowledge and research competence of the learners. Mentor education should include some practical training and development of certain mentoring skills. To minimise these disadvantages, modular systems of the master programme with components of field practice as a mentor could be offered.

\section{Flexible short-term in-service education}

After analysing the scenario of the short-term in-service education programmes, we can assume that this approach offers a more stable partnership between training providers and schools, thus creating the possibility of developing a community of practitioners through enhanced information exchange. These types of short-term programmes can respond to the immediate needs of the schools, and allow implementing induction programmes in a short time frame, avoiding the previously mentioned two-year gap. The frame of the inservice courses enables the design of the course based on learners' needs and prior competences. One of the disadvantages of this scenario is uncertainty in unstable circumstances. There is a risk of having mentor education programmes vary on levels of quality based on the conditions of an open market of in-service education of teachers, where various institutions and organisations including NGOs can provide mentor education programmes without a well-developed system of accreditation and quality assurance. Additionally, there is a lack of knowledge about mentoring among in-service educators and not enough resources to develop this capacity. In this context, we can raise questions about how to select institutions which can offer mentor education programmes.

Comparatively analysing the two proposed scenarios, we should assume that there is a need for certain flexibility in mentor education. Thus, we cannot delineate which scenario is preferable. In future discussions we should consider the following aspects having strong influence on the system:

- the prior experience and competences of the persons considered to become a mentor;

- $\quad$ individual characteristics of the future mentor;

- the needs of the school where the future mentor will work (short-term needs versus long-term needs).

As mentor education has been a matter of debate in Romania for some 
years, there are some initiatives in constructing the content of the programmes for mentor education. For example, at the University of Bucharest, there is a master degree programme titled Mentoring in education. The content of this programme includes the following topics: human resources management in education, mentor competences, partnership in education, reflexive teacher, communication and interaction in mentoring activities, and practical approaches to mentoring. Considering the content of the mentor education programme, we need to take into account that there is no frame for mentor education. We should be aware in which context mentor education can take place. In future research, we will aim to identify the best content for mentor education suitable to the proposed scenarios.

\section{Discussion}

Analysing comparably the two national contexts, as well as advantages and disadvantages of the proposed scenarios for the Romanian context and the Estonian example, we need to develop further discussions in two main areas: 1) contextual factors which needed to be taken into consideration planning mentor education, 2) sustainability of the mentoring.

\section{Contextual factors}

First, in comparison to the Estonian mentor education approach, the academic scenario proposed for the Romanian system is much more regulated than the education of induction mentors in Estonia. There are several reasons for a decentralised system in Estonia. Based on the TALIS Survey (2013), Estonian schools have greater autonomy than in many European countries, and school leaders are responsible for teachers' professional development. Furthermore, headmasters are responsible for selecting and appointing the mentor for newly qualified teachers. In Estonia, mentoring is part of the workload of teachers (teaching hours are reduced or mentoring is considered to be participation in school development activities). In this case, the school leaders' role is very influential, and the effectiveness of mentoring depends on concrete school leadership. In Romania, taking into account the centralised approach, there are several regulations on the state level about teachers' workload, tasks and the role of the headmaster is more limited.

Second, in Romania, teacher education does not require master degree level education, but in Estonia, there is a master level teacher education requirement and almost all teachers have a master degree. This means that many Romanian teachers may be more willing to continue their formal education in higher education to obtain a higher academic degree. Especially in the context 
that the $3+2$ higher education system is approved on a policy level and is in the implementation phase. The importance of master level education is acknowledged among in-service teachers and in society generally.

Third, we need to look at the lack of motivation among teachers in becoming mentors and their engagement in specific educational paths to becoming mentors in the absence of explicit advantages (financial, status, the disclaimer at the basic norm, etc.). For example, in Estonia teachers historically took part in in-service education. According to the TALIS Survey (2013), 93\% of teachers took part in professional development courses within the last 12 months. Furthermore, according to the educational policy, every school has to have a professional development plan for all teachers and headmasters who are responsible for supporting teachers' learning. In Romania, this policy has not yet been implemented; thus, this could be taken into consideration when choosing to develop a training programme for mentors.

In future research, we should take into consideration the compiling mentor education programmes in Romania, the free market of training providers that will not guarantee the equal quality of offered courses, and the coherence of induction mentoring according to the national aims. Comparing two countries, Estonia is relatively small (approx. 237,00o general school teachers in Romania versus 14,500 in Estonia); there are two universities responsible for teacher education including induction mentor education. This is not the case in Romania, because there are 83 universities responsible for initial and continuing teacher education and hundreds of private providers of courses in continuing professional development. Thus, it is quite difficult to have the same quality in all programmes within a very flexible framework.

\section{Sustainability of the mentoring}

Cooperation between schools and mentor education institutions is crucial for maintaining a successful and sustainable mentoring network at all levels. In Estonia, universities are responsible for mentor education and organising group seminars for novice teachers. The feedback from novice teachers is used as input for the development process of mentor education. In Romania, regardless of the chosen scenario, there is a need to create a connection between educational institutes (higher education institutes, private training providers, NGOs, etc.) and mentors' workplace (schools). Therefore, educational institutes can gather feedback from mentors and representatives of schools to improve their mentor education curriculum.

To balance mentors' individual needs and the institutional or national needs, there should be a focus point in any discussion regarding mentor 
education. Thus, we may argue that a centralised approach helps to support changes in the educational system. In a more flexible scenario, it is possible to develop the course according to the needs of participants and focus on professional development of every single teacher. If the state or national educational system aims towards a paradigm shift, a more centralised system is preferred, and mentors as change agents can support the professional development of the new generation of teachers who will adopt student-centred approaches to teaching.

We believe that it is mandatory to approach mentor education from a professionalised perspective and offer flexibility in choosing alternative educational paths for the teachers who want to become mentors.

\section{Conclusion}

The national, social, political, and educational context must be taken into consideration in implementing and developing policies in education. We need to consider how to learn from the practices of other countries without adapting them directly to the certain national context.

Analyzing the Estonian system, we could draw the conclusion that placing continued effort and resources into developing teacher education and mentor education is a worthwhile long-term investment for beginning teachers and for all educational systems in general. After years of coherent educational policy implementation and financial sustainability, mentoring is becoming a natural part of the school culture in Estonia. Continuing cooperation with mentor supports beginning teachers'cooperation with other colleagues and involvement into school development processes (Eisenschmidt, Oder \& Reiska, 2013). The most challenging aspect of the induction programme in Estonia is school leaders' awareness and willingness to create a good atmosphere for mentorship at the school level (Löfström \& Eisenschmidt, 2009).

Considering possible scenarios for Romanian context, we may conclude that multiple approaches can be co-exist in mentor education, but they have slightly different goals and meet diverse needs in the educational system. From the perspective of research-based policy, the development of some pilot projects should be implemented to analyse the possible scenarios in practice. Based on the results from pilot projects, the nationwide system can be worked out.

In this paper, we did not analyse the possible content of mentor education in the Romanian system. Still, in choosing possible scenarios we have to consider these mentor education approaches in the light of concepts on mentoring. For example, in the humanistic approach, as Wang and Odell (2002) 
assert, mentorship emphasis must emphasise the importance of emotional support and socialising novices into the organisation and profession. Therefore, we believe that this mentoring approach may be best suited for school-based in-service training for mentors in order to better understand the context in which novices work. The situated apprenticeship perspective puts emphasis on the mentors' ability to articulate practical knowledge (ibid.). Thus, mentorseducation should have a more comprehensive approach with emphasis on a well-developed and stable partnership between teacher education, institutions, and schools. The critical constructivist approach (Feiman-Nemser, 2001; Wang, Odell, 2002), offers the possibility to better meet national needs, creates the possibility of developing a community of practitioners by enhancing knowledge exchange and creating new practices.

Considering that induction is an essential phase in teachers' professional development we believe that broad discussions are needed at all levels. At a micro-level (individual and institutional), we should identify if and how schools as organisations can support novice teachers and mentoring within the school context, regarding how to select mentors and regulate their workload, how to create a collaborative culture to support newcomers, etc. At a macro-level (national and European levels), we should investigate who mentor educators are, and what the competences should be of mentor educators, and how to allow flexible pathways to educate mentors.

\section{References}

Bullough, R. V. (2005). Being and becoming a mentor: school-based teacher educators and teacher educator identity. Teaching and Teacher Education, 21(2), 143-155.

Eisenschmidt, E. (2006). Implementation of Induction Year for Novice Teachers in Estonia.

Dissertations on Social Sciences-Abstract. Tallinn: Tallinn University Publishing House.

Eisenschmidt, E., Oder, T., \& Reiska, E. (2013). The Induction Programme - Teachers' Experience after Five Years of Practice. Mentoring and Tutoring: Partnership in Learning, 21(3), 241-257.

Gravey, B., \& Alred, G. (2000). Educating mentors. Mentoring and Tutoring: Partnership in Learning, 8(2), 113-126. Haridussilm. Retrieved 03.08.2016 from http://www.haridussilm.ee.

Hartnett, A., \& Carr, W. (1995). Education, Teacher Development and Struggle for Democracy. In J. Smyth (Ed.), Critical Discourses on Teacher Development (pp. 39- 53). London: Cassell, Wellington House.

Huling, L., \& Resta, V. (2001). Teacher mentoring as professional development. ERIC digest.

Retrieved 15.09.2015 from http://www.eric.ed.gov/ERICWebPortal/contentdelivery/servlet/ ERICServlet?accno=ED460125.

Ingleby, E., \& Hunt, J. (2008). The CPD needs of mentors in post-compulsory Initial Teacher 
Training in England. Journal of In-Service Education, 34(1), 61-74.

Iucu, R., \& Stîngu, M. (2013). Training induction mentors: alternative policy scenarios. In: 5th International Conference EDU-WORLD 2012 - Education Facing Contemporary World Issues, Procedia - Social and Behavioral Sciences, 76(153), 931-934. Retrieved 15.04.2013 from http://dx.doi. org/10.1016/j.sbspro.2013.04.237.

Jones, M. (2010). The needs of mentors. In K. Smith, \& M. Ulvik (Eds.), Mentoringnovice teachers: national and international perspectives (pp. 115-129). Oslo: Universitetsforlaget.

Löfström, E., \& Eisenschmidt, E. (2009). Novice teachers' perspectives on mentoring: The case of the Estonian induction year. Teaching and Teacher Education, 25(5), 681-689.

National Institute of Statistics (2015). Retrieved 25.07.2016 from http://www.insse.ro/cms/. New priorities for European cooperation in education and training (2015). Communication From The Commission To The European Parliament. Retrieved 03.08.2016 from http://ec.europa.eu/education/ documents/et-2020-draft-joint-report-408-2015_en.pdf.

OECD.(2014). TALIS 2013 results: An international perspective on teaching and learning. OECD

Publishing. Retrieved 20.09.2015 from http://dx.doi.org/10.1787/9789264196261-en.

Õpetajate koolituse raamnõududed [Framework Guidelines for Teacher Education] (2000).

Retrieved 27.08.2014 from https://www.riigiteataja.ee/akt/812791.

Orland-Barak, L., \& Klein, S. (2005). The expressed and the realized: mentors' representations of a mentoring conversation and its realization in practice. Teaching and Teacher Education, 21(4), 379402.

Poom-Valickis, K. (2007). Novice teachers' professional development across their induction year. Tallinn University. Dissertation on Social Sciences. Tallinn: Tallinn University Publishing House. Romanian National Law of Education (1/2011). Retrieved 20.04.2014 from www.edu.ro.

SEC Developing coherent and system-wide induction programmes for beginning teachers - a handbook forpolicymakers (2010). European Commission Staff Working Document. Retrieved 05.06.2014 from http://ec.europa.eu/education/library/publications/handbooko410_en.pdf.

Stîngu, M. (2013). Induction of newly qualified teachers: needs, implications and opportunities.

(Doctoral thesis). Bucharest: University of Bucharest.

Strengthening teaching in Europe. EC policy note (2015). Retrieved 03.08.2016 from http://ec.europa. eu/education/library/policy/teaching-profession-practices_en.pdf.

Ulvik, M., \& Sunde. E. (2013). The impact of mentor education: does mentor education matter? Professional Development in Education, 39(5), 754-770.

Wang, J., \& Odell, S. J. (2002). Mentored Learning to Teach According to Standard-Based Reform: A Critical Review. Review of Educational Research, 72(3), 481-546.

Yee, S., \& Fan Tang, S. Y. (2012). Knowledge base of mentoring and mentor preparation. In S. Flecher, \& C. A. Mullen (Eds.), The Sage Handbook of Coaching and Mentoring in Education (pp. 478-493). Sage: London. 


\section{Biographical note}

Eve Eisenschmidt (PhD) is Professor of Education Policy and Management in Tallinn University, Estonia. She has worked as teacher, teacher-educator and vice-rector of the Tallinn University. Her research is mainly focusing on teachers' professional development, escpecially newly qualified teachers' socialization and mentoring in the workplace. She lead national project on developing policy framework for induction programme for beginning teachers.

Mihaela Stîngu (PhD) is Assistant Lecturer at the University of Bucharest and has a PhD in Educational Sciences at University of Bucharest in the field of tteacher education. The main research interests, among others are: induction of newly qualified teachers and academics, access of vulnerable groups to education and relationship between research and educational policies.

Romiț Ă IUCU (PhD) is vice-rector at the University of Bucharest and Professor in the field of Higher Education Pedagogy, Teacher Training and Group Management at the Faculty of Psychology and Educational Sciences, Department for Education. He has held several management positions and had a great influence on processes of teacher education in Romania. His research is mainly focusing on teachers' professional development and developing in higher education. 